\title{
OPTIMALISASI PERAN PERGURUAN TINGGI DALAM \\ PEMBERDAYAAN UMKM MELALUI \\ KERJASAMA JOINT VENTURE PROFIT SHARING
}

\author{
Arif Wibowo
}

\author{
Fakultas Ekonomi Universitas Negeri Yogyakarta
}

\begin{abstract}
ABSTRAK
Tulisan ini bertujuan untuk melakukan analisis atas kemungkinan terjalinnya kerjasama yang saling menguntungkan antara sektor UMKM (Usaha Mikro Kecil Menengah) dengan Perguruan Tinggi. Sebuah bentuk kerjasama dengan skema Joint Venture Profit Sharing (JVPS) merupakan sebuah alternatif desain yang akan dianalisis dalam tulisan ini.

UMKM hingga saat ini menghadapi berbagai permasalahan klasik, seperti permodalan, pemasaran, produksi dan teknologi, pengelolaan Sumber Daya Manusia, dan permasalahan akses informasi dan jaringan. Sementara itu, Perguruan Tinggi (PT) di satu sisi adalah tempat bertemunya para ahli dari berbagai bidang dan tempat dikembangannya bermacam ilmu dan teknologi yang sebenarnya sangat dibutuhkan oleh UMKM. JVPS yang merupakan bentuk penyertaan modal dengan hak keterlibatan dalam pengelolaan usaha adalah bentuk kerjasama yang sangat dibutuhkan oleh UMKM sekaligus bisa dipenuhi leh PT.

Diperlukan sebuah Unit Pengelola Kerjasama JVPS di Perguruan Tinggi yang bertugas mengelola penarikan dana-dana PT untuk tujuan pemberdayaan UMKM. Dana yang terkumpul untuk kemudian dialokasikan kepada UMKM yang potensial, dengan sebuah perjanjian kerjasama yang mengatur hak dan kewajiban masing-masing pihak. Perjanjian ini menjadi syarat mutlak sebelum kerjasama dilakukan, untuk menjamin bahwa hak semua pihak yang terlibat akan terlindungi dengan baik.
\end{abstract}

Kata Kunci: UMKM, Joint Venture Profit Sharing

\section{A. PENDAhuluan}

Usaha Mikro Kecil dan Menengah (UMKM) adalah sektor usaha yang mempunyai daya tahan yang cukup handal dalam menghadapi berbagai terpaan krisis, baik krisis moneter maupun krisis keuangan lainnya. Selain itu, peran UMKM dalam Perekonomian Nasional juga sangat besar. 
Diketahui bahwa UMKM memberikan sumbangan yang cukup signifikan atas Produk Domestik Bruto (PDB) Indonesia. Menurut Data Kementrian UKM dan Koperasi, dilihat dari Produk Domestik Bruto (PDB), UMKM memberikan sumbangan sebesar 57.12\% dari keseluruhan PDB Nasional. Selain itu, dari sisi penyediaan lapangan kerja, sektor UMKM menyumbangkan sebanyak 97.22\% dari seluruh lapangan kerja yang ada.

Sedangkan dilihat dari jumlah Unit Usaha tahun 2012, Unit usaha Sektor UMKM tercatat sebanyak 56.539.560. Secara keseluruhan, dari semua sektor usaha yang ada di Indonesia, 99,99\% nya adalah sektor UMKM.

Dari angka tersebut tercatat, jumlah unit usaha ukuran menengah (dengan omset/tahun Rp2,5 miliar-Rp50 miliar dan aset Rp500 juta-Rp10 miliar) baru 48.977 Unit atau hanya 0,09 persen dari total unit usaha. Sedangkan usaha kecil (dengan omset/tahun Rp300 juta-Rp2,5 miliar dan aset Rp50 juta-Rp500 juta) sebanyak 629.418 unit atau sebanyak 1,11 persen dari total unit usaha. Unit usaha terbanyak adalah dari usaha sektor mikro (dengan omset/tahun sampai dengan Rp300 juta dengan aset hingga Rp50 juta), yakni sebanyak 55.586.176 unit usaha atau sebanyak 98,79 persen dari total unit usaha.

Namun demikian, dari peran dan sumbangan UMKM yang sedemikian sentral, basis UMKM sendiri dan ekonomi rakyat secara umum ternyata masih sangat lemah dalam visi, sikap wirausaha, dan manajemen bisnis yang paling mendasar. Eksistensi Usaha kecil diakui masih belum bisa terlepas dari beberapa permasalahan klasik yang menyertainya, terutama masalah akses modal dan kesempatan mendapatkan peluang usaha, disamping masalah produksi, pemasaran, jaringan kerja, dan teknologi.

Telah banyak cara yang dilakukan untuk membuat UMKM menjadi kuat, mandiri, memiliki daya saing, dan menyokong pemulihan perekonomian nasional. Namun demikian hal itu semua belum menunjukkan hasil yang menggembirakan.

Dalam makalahnya, Ina Primiana mengidentifikasi beberapa masalah yang dialami oleh UKM adalah permodalan, pemasaran, produksi/teknologi, sumber daya manusia, dan dukungan pemerintah. Secara rinci, permasalahan tersebut adalah sebagai berikut: 
1. Permodalan, meliputi:

a. Modal kecil, sulit memenuhi pesanan.

b. Sulit mendapatkan kredit dari bank. Sejak krisis moneter tahun 1998, bank-bank di Indonesia sangat hati-hati memberikan kredit.

c. Kurang mampu mengadakan perencanaan, pencatatan, pelaporan. Tidak dapat membuat neraca maupun laporan laba/rugi.

d. Tercampurnya antara keuangan perusahaan dengan keuangan keluarga.

2. Pemasaran:

a. Kurang dapat melihat peluang pasar/selera pasar

b. Akses terhadap informasi yang kurang

c. Terbatasnya tempat pemasaran

d. Kemampuan negosiasi yang lemah, sehingga berakibat kerugian pada sistem pembayaran dan perjanjian kontrak

e. Kurang kerjasama dengan perusahan besa, sesama UKM, pihak luar negeri, terutama dalam hal promosi

f. Kurang mampu merancang strategi bisnis.

3. Produksi/Tekologi

a. Kurangnya pengetahuan tentang bagaimana memproduksi barang yang berkualitas, efisien, dan diserahkan tepat waktu.

b. Tidak adanya transfer teknologi dari usaha besar

c. Tidak melakukan riset dan pengembangan

d. Tidak mengerti pentingnya kerjasama dengan pihak suplier

e. Tidak adanya proses perbaikan yang berkesinambungan (continuous improvement)

4. Sumber Daya Manusia

a. Pendidikan rendah

b. Rendahnya jiwa wirausaha

c. Keahlian terbatas

d. Rendahnya produktivitas kerja

e. Tidak ada pembagian kerja (job description) 


\section{JURNAL NOMINAL / VOLUME II NOMOR II / TAHUN 2013}

\section{Pemerintah}

a. Kurangnya dukungan dengan berbagai kebijakan yang berpihak pada UKM

b. Kurangnya menciptakan lingkungan yang kondusif. Pemerintah lebih mengutamakan pada perbaikan indikator makro, dan kurang memberi perhatian lebih pada indikator mikro agar sektor riil/UMKM bisa bergerak lebih leluasa.

\section{B. PERMASALAHAN}

Secara khusus, pengamatan atas aspek modal atau pembiayaan UMKM dapat dikemukakan beberapa catatan awal (Yunus, 2003; Robinson, 2004; Untoro, 2004) adalah sebagai berikut:

Pertama, Masih terdapat resistensi secara umum dari pihak perbankan daerah dalam melaksanakan penyaluran kredit bagi UMKM yang ternyata dianggap lebih bersifat fund chanelling saja ketimbang sebagai fungsi intermediasi yang memiliki perpektif komersial yang menjanjikan keuntungan.

Kedua, dari sisi UMKM tampak masih selalu menganggap adanya kendala birokrasi yang memunculkan kurangnya kases pada kredit perbankan di samping tidak cukupnya aset mereka untuk jaminan (collateral).

Ketiga, masalah kurang tersedianya dana dan sumber pendanaan dengan biaya dana yang terjangkau.

Keempat, terjadinya double financing, kompetisi tidak adil, lemahnya informasi dan jaringan, baik antara UMKM maupun antar penyedia jasa keuangan (bank dan non-bank serta lembaga terkait lainnya) yang kemudian berpotensi melahirkan masalah moral hazard dan adverse selection.

Kelima, diperlukan semacam bantuan advokasi, pembinaan, atau suatu hasil kajian komprehensif yang dapat mendorong dan lebih memungkinkan UMKM untuk memnuhi kriteria pendanaan (lending criteria).

Dari lima permasalahan pendanaan di atas, perlu dicarikan solusi alternatif untuk memberikan peluang bagi UMKM agar bisa mendapatkan akses pendanaan, terutama dengan mencari terobosan dalam mengatasi permasalahan kedua, ketiga dan kelima. Dengan kata lain, diperlukan solusi alternatif agar UMKM bisa 


\section{JURNAL NOMINAL / VOLUME II NOMOR II / TAHUN 2013}

mendapatkan akses pendanaan yang mensyaratkan biaya dana (cost of fund) yang rendah, dengan jaminan yang terjangkau, serta adanya sebuah lembaga atau pihak yang bersedia memberikan advokasi (pembinaan) agar UMKM mampu mengembangkan usahanya ke arah yang benar dan profitable.

\section{PEMBAHASAN}

Joint Venture Profit Sharing (JVPS) adalah kerja sama antara dua pihak atau lebih, dimana masing-masing pihak dapat mengumpulkan modal mereka untuk membentuk suatu usaha (perserikatan) sebagai sebuah badan hukum (legal entity). Dalam bentuk kerjasama ini, kedua pihak ikut andil dalam penyertaan modal (equity participation), dan masing-masing dapat terjun langsung secara bersamasama dalam proses manajemen.

Apabila usaha yang dijalankan mendapat untung, maka keuntungan akan dibagi berdasar nisbah bagi hasil yang ditentukan di muka atas dasar kesepakatan kedua belah pihak, secara proporsional berdasarkan besar kecilnya modal yang disertakan atau berdasarkan keikutsertaannya dalam proses manajemen. Namun apabila usahanya merugi, kedua pihak secara bersama-sama menanggung kerugian tersebut.

Dalam aplikasinya, JVPS bisa diterapkan dalam kerjasama pembiayaan, di mana pihak pemilik modal bekerjasama dengan pengusaha dalam menjalankan usaha, dengan kontribusi modal dan pembagian keuntungan sesuai kesepakatan yang dibicarakan dan ditentukan dalam kontrak di awal kerjasama. Pembiayaan JVPS bisa dijalankan dalam berbagai bentuk, di antaranya:

Pertama, JVPS permanen (continous JVPS), di mana pihak pemilik modal merupakan partner tetap dalam suatu proyek atau usaha. Model ini jarang dipraktikkan, namun JVPS permanen ini merupakan alternatif menarik bagi investasi surat-surat berharga atau saham, yang dapat dijadikan salah satu portfolio investasi.

Kedua, JVPS digunakan untuk pembiayaan modal kerja (working capital), di mana pemilik dana merupakan partner pada tahap awal dari sebuah usaha atau proses produksi. Dalam model pembiayaan ini, pihak pemilik dana akan menyediakan sejumlah uang untuk membeli aset atau alat-alat produksi, begitu juga dengan partner JVPS lainnya. 


\section{JURNAL NOMINAL / VOLUME II NOMOR II / TAHUN 2013}

Setelah usaha berjalan dan dapat mendatangkan profit, porsi kepemilikan bank atas aset dan alat produksi akan berkurang karena dibeli oleh para partner lainnya, dan pada akhirnya akan menjadi nol, model pembiayaan ini lebih dikenal dengan istilah deminishing JVPS. Model ini yang banyak diaplikasikan dalam perbankan syariah dalam bentuk Produk Pembiayaan Musyarakah.

Ketiga, JVPS digunakan untuk pembiayaan jangka pendek. JVPS jenis ini bisa diaplikasikan dalam bentuk project finance atau pembiayaan perdagangan, seperti ekspor, impor, penyediaan bahan mentah atau keperluan-keperluan khusus nasabah lainnya.

Mengenai bagi hasil, sebenarnya ada dua metode yang dapat digunakan, yaitu profit sharing (bagi laba) atau revenue sharing (bagi pendapatan). Jika memakai metode revenue sharing, berarti yang dibagi hasil antara bank dan nasabah pembiayaan adalah pendapatan tanpa dikurangi dengan biaya-biaya. Sedangkan apabila menggunakan metode profit sharing, maka yang dibagi hasil antara bank dengan nasabah pembiayaan adalah pendapatan setelah dikurangi biaya-biaya (laba).

Pembiayaan JVPS bukan model pinjaman yang mensyaratkan pengembalian dengan nominal kompensasi yang sudah ditentukan di muka. Dalam JPVS, proporsi pembagian keuntungan dari usaha yang dijalankan sudah ditentukan di awal, bukan jumlah nominal bagian keuntungan pemilik dana. Dengan model ini diharapkan, tiap-tiap pihak yang terlibat, baik pengusaha maupun pemilik dana, akan menanggung risiko yang sama (sesuai dengan proporsi modal yang digunakan) atas keberlangsungan usaha dan laba atau rugi yang akan didapatkan.

Selain prinsip keadilan, konsep ini akan mengarahkan pemilik dana untuk secara sunguh-sunguh memperhatikan kesehatan dan profitabilitas usaha yang dijalankannya tersebut. Semakin baik kerjasama usaha dibangun, akan semakin menguntungkan usaha yang dijalankan, maka semakin besar kompensasi yang menjadi hak dari masing-masing pihak, termasuk pemilik dana.

Karena sifat dasarnya, kerjasama JVPS tidak boleh mensyaratkan adanya jaminan dari pihak pengusaha kepada pihak pemilik dana. Risiko rugi yang dihadapi oleh usaha kerjasama merupakan risiko bersama yang harus dihadapi dan diantisipasi bersama. 
Dalam dunia perbankan, pembiayaan JVPS hampir tidak pernah ada yang diterapkan dengan menggunakan dasar konsep profit and loss sharing contract secara penuh sebagaimana konsep dasar dari jenis kerjasama ini. Beberapa permasalahan yang dikemukakan dari aplikasi konsep profit and loss sharing contractini diantaranya:

1. Kecenderungan sebagian besar (atau hampir semua) pemilik dana termasuk bank dan lembaga keuangan untuk meletakkan kelebihan dana dimilikinya pada tempat yang benar-benar aman. Kecenderungan ini, menjadikan pemilik kelebihan dana, termasuk bank dan lembaga keuangan lainnya untuk meminjamkan uangnya hanya pada proyek atau usaha yang bisa menjamin pengembalian uangnya disertai dengan keuntungan yang dipersyaratkan.

2. Pengelolaan (manajemen) usaha yang belum terbukti berhasil menjadikan pihak yang mempunyai kelebihan dana seringkali mensyaratkan adanya jaminan (agunan).

3. Terbuka lebarnya terjadi moral hazard dan adverse selection pada pembiayaan dengan konsep JVPS menjadikan pemilik dana tidak memberikan kepercayaan bagi masing-masing pihak untuk menjalankan kerja sama kemitraan dengan menerapkan konsep ini secara penuh.

Di sisi lain, Perguruan Tinggi (PT) adalah sebuah lembaga pendidikan yang diharapkan mampu menjembatani dan mengatasi beberapa kelemahan di atas. Perguruan Tinggi (PT) merupakan kelanjutan pendidikan menengah yang diselenggarakan untuk mempersiapkan peserta didik untuk menjadi anggota masyarakat yang memiliki kemampuan akademis dan profesional yang dapat menerapkan, mengembangkan, dan menciptakan ilmu pengetahuan, teknologi, dan kesenian (UU No 2 th 1989, Pasal 16, ayat (1).

Sedangkan UU Sisdiknas pasal 20 ayat (2) menyatakan bahwa Perguruan tinggi berkewajiban menyelenggarakn pendidian, penelitian, dan pengabdian kepada masyarakat.

Dari dua Undang-Undang tersebut, kita bisa menyatakan bahwa pemberdayaan UMKM sebenarnya bukan saja menjadi hak perguruan tinggi untuk ikut terlibat didalamnya, namun bahkan bisa kita maknai sebagai sebuah kewajiban. 


\section{JURNAL NOMINAL / VOLUME II NOMOR II / TAHUN 2013}

Dalam konteks permasalahan yang kita kemukakan dalam tulisan ini, perguruan tinggi berkewajiban untuk memberikan akses dan dukungan sepenuhnya untuk pemberdayaan UMKM. Beberapa kekuatan (strenght) yang dimiliki oleh Perguruan Tinggi yang bisa dimanfaatkan untuk percepatan pemberdayaan UMKM diantaranya:

1. Perguruan Tinggi adalah tempat berkumpulnya para ahli dari berbagai disiplin ilmu. Salah satu permasalahan yang banyak terjadi pada UMKM adalah persoalan yang berkaitan dengan pemasaran, teknik produksi, pengelolaan SDM, serta lemhnya pencatatan dan pembuatan laporan keuangan serta pemanfaatannya.

Di sisi lain, pergurun tinggi merupakan tempat bertemunya dan dikembangkannya teknik-teknik dan strategi untuk semua permasalahan di atas. Di institusi inilah para ahli berkumpul, berdiskusi, dan mengajarkan ilmu keahlianya. Potensi pergurun tinggi yang luar biasa inilah yang sebenarnya sangat dibutuhkan oleh UMKM dalam upayanya merencanakan pegembangan usaha, memastikan usaha berjalan dengan arah nyang benar, dan melakukan review atas kegiatan-kegiatan yang sudah dijalankan untuk me-revise beberapa penyimpangan yang mungkin terjadi.

Dengan potensi ini, dalam Perguruan Tinggi mempunyai peluang yang cukup besar dalam kerjasama kemitraan dengan UMKM dalam bentuk Joint Venture Profit Sharing (JVPS). Dengan kemitraan ini, Perguruan Tinggi bisa berperan memberikan masukan dan ide-ide untuk pengelolaan usaha dengan lebih terarah dan terencana. Bentuk seperti ini bukan semata bentuk Pengabdian Masyarakkat dengan UMKM sebagai Obyeknya, namun lebih dari itu, Perguruan Tinggi melalui sebuah unit pegembangan UMKM menjadi partner usaha bagi UMKM. Atas kontribusi pengelolaan (dan kotribusi penyertaan dana), Pergurun Tinggi mempunyai hak untuk mendapatkan bagian keuntungan nyang dihasilkan dari kerja sama tersebut.

2. Perguruan Tinggi mempunyai sumber pendanaan untuk kegiatan penelitian dan pengabdian. Berbagai sumber dana Perguruan Tinggi bisa digunakan untuk pemberdayaan UMKM, baik dana dari Universitas, lembaga, fakultas, jurusan, atau bakan dana perseorangan. Satu prinsip yang harus diperhatikan dalam 


\section{JURNAL NOMINAL / VOLUME II NOMOR II / TAHUN 2013}

pengelolaan dana ini adalah bahwa dana kemitraan yang akan dilibatkan dalam pemberdayaan UMKM bukan merupakan dana hibah bagi UMKM, akan tetapi adalah dana penyertaan (pembiayaan) bagi UMKM.

Dana yang dilibatkan dalam JVPS bukan merupakan dana tetap bagi UMKM, akan tetapi semacam pinjaman yang nantinya harus dikembalikan dengan berakhirnya masa kerja sama tersebut. Atas keuntungan yang dihasilkan, masing-masing pihak mendapatkan bagian sesuai dengan kontribusi yang dispakati di awal perjanjian (kontrak). Risiko kerugian yang mungin dialami, juga menjadi tanggungan bersama semua puak yang terlibat $d$ dalamnya.

3. Perguruan Tinggi mempunyai fasilitas, jaringan, dan sarana yang dibutuhkan untuk pengembangan UMKM. Perguruan tinggi mempunyai laboratorium, alat-alat produksi, bahan dan sarana percobaan, serta jaringan yang luas yang seringkali dibutuhkan oleh UMK dalam pengembangan usahanya.

Dalam hal pemasaran produk, Perguruan Tinggi mempunyai banyak informasi dan peluang promosi, pemanfaatan media publikasi, dan berbagai lat peragaan untuk mengenalkan, mengedukasi, dan mempromosikan produk-produk UMKM. Dalam hal produksi barang, Perguruan tingi juga mempunyai banyak bengkel-bengkel kerja dan alat-alat produksi yang selalu dikembangkan sesuai dengan kebutuhan kerja. Dalam hal pencatatan dan pembukuan,

Perguruan Tinggi mempunyai media dan sarana pelatihan dan teknik-teknik analisisnya. Daam Hal Sumber daya Manusia, Perguruan Tinggi mempunyai banyak cara dan sumber untuk mendapatkan tenaga kerja terlatih yang dibutuhkan oleh UMKM.

Dalam kerjasama JVPS yang dilakukan, kontribusi atas pemakaian sarana dan prasarana PT ini harus dibicarakan di awal kerjasama. Ketidakjelasan atas hak dan tanggungjawab masing-masing pihak harus dihilangkan, dengan tidak mengabaikan pertimbangan ekonomi dan sosial.

4. Perguruan Tinggi bisa menjadi lembaga penjamin Pembiayaan dari Bank. Dalam kasus lain, seandainya PT tidak mempunyai cukup dana yang bisa disertakan dalamkerjasama JVPS, PT bisa bertindak semata sebagai lembaga advocasi bagi UMKM. PT bisa berperan dalam memberikan pertimbangan atas studi kelayakan yang dibuat oleh UMKM, dan menjadi konsultan 
manajemen sekaligus memberikan jaminan (guarantee) kepada bank atau lembaga pemberi pinjaman bahwa UMKM yang bersangkutan adalah UMKM yang profitable, dan mampu merealisasikan laba seperti yang direncanakan. Atas peran ini, PT bisa menjembatani permasalahan permodalan yang dialami oleh UMKM dengan mengakses pembiayaan yang tidak mensyaratkan agunan dalam bentuk riel asset.

\section{PENUTUP}

Dari uraian di atas, bisa ditarik beberapa kesimpulan:

1. JVPS bisa dilaksanakan sebagai alternatif solusi bagi UMKM yang membutuhkan tambahan dana untuk pengembagnan usahanya.

2. Pelaksanaan JVPS mensyaratkan keterlibatan masing-masing pihak dalam pengelolaan usaha.

3. Perguruan Tinggi (PT) dengan segala kelebihan yang dimiliki, merupakan pihak yang mempunyai potensi angat besar untuk melakukan kerjasama JVPS dengan UMKM.

4. PT akan berperan sebagai partner. Dana-dana pengabdian dialokasikan sebagai dana untuk penyertaan, bukan bantuan. Target pengembalian dana ini, dan target kemajuan UMKM akan bisa dijamin oleh sumber daya ahli yang ada di Perguruan tinggi.

5. Diperlukan sebuah wadah di perguruan tinggi untuk operasionalisasi kerja sama JVPS. Wadah ini bertugas mengakomodasikan dana-dana yang ada dan mengorganisasikan agar dana penyertaan bagi UMKM benar-benar bisa dikelola dengan baik, manfaat dan menguntungkan. Dengan kontribusi dan keseriusan pengelolaan usaha oleh PT dan mitra, usaha yang dijalankan mempunyai harapan besar untuk tumbuh dan berkembang. Dengan ini, diharapkan para pemilik dana mendapatkan bagian yang menguntungkan.

6. Dengan itu, maka makna ibadah dalam kerja bukan sekadar slogan tanpa makna, tetapi akan jauh lebih kaya makna. InsyaAllah. 


\section{E. DAFTAR PUSTAKA}

Abdullah, Daud Vicary dan Keon Chee, Buku Pintar keuangan Syariah, Jakarta: Penerbit Zaman, 2012.

Robinson, M.S., The Microfinance Revolution, Vol. 1-3 (Sustainable Finance for The Poor; Lesson from Indonesia; The Emerging Industry, Washington, D.C.: The World bank, 2004

Primiana, Ina, "The escalating Small and Medium Enterprise (SME's) Competitiveness in Indonesian Through Entrepreneurial Skill", dalam Menggerakkan Sektor Riel UKM dan Industri, Bandung: Penerbit Alfabeta, 2009

Untoro, Default Risk and Penjaminan Kredit UKM, "Bank Indonesia Working Paper WP/01/PPSK/05, Pusat Pendidikan dan Studi Kebanksentralan, Bank Indonesia, Jakarta, 2004

Yaumiddin, Umi Karomah, Usaha bagi Hasil: Antara teori dan Praktik, Yogyakarta: Kreasi Wacana, 2010

Yunus, M., A Note on ADB's Consultation Workshop Results on SME's Development in EAGA: The Direction of SME's Financiual Supports for Sulawesi and Kalimantan cases." A reviewed Paper of the ADB's Businesss Consultant for SME's, Makassar, 2003

Zaim Saidi, Tidak Syar'inya Bank Syariah di Indonesia, Yogyakarta: Delokomotif, 2010 